\title{
Федір ЗІНЧЕНКО
}

\section{РОЗВИТОК ГАОБАМЬНИХ БIРКОВИХ МЕРЕХ}

Досліджено вплив мережевого ефректу або ефекту ліквідності на стратегію поведінки фрондових бірж на сучасному етапі розвитку світового ринку капіталу. Виявлено два основні напрямки розвитку біржової мережевізації: через інтеграцію та використання сучасних комунікаційних засобів окремими торгівельними платооормами. Визначено специфріку різних форм міжнародної інтеграції бірж: від фоормального співробітництва до корпоративного злиття. Проаналізовано специфріку роботи провідних регіональних біржових об'єднань на прикладі MILA, SEE Link ma Stock Connect. Визначена провідна роль інформаційно-комунікаційних провайдерів у побудові сучасних глобальних біржових мереж.

Ключові слова: біржа, ринок капіталу, мережевий ефект, регіональна інтеграція, точка допуску.

\section{Фёдор ЗИНЧЕНКО}

\section{Развитие глобальных биржевых сетей}

Исследовано влияние сетевого эфрфекта или эффректа ликвидности на стратегию поведения фонндовых бирж на современном этапе развития мирового рынка капитала. Выявлено два основных направления развития биржевой сетевизации: через интеграцию и использование современных коммуникационных средств отдельными торговыми платформами. Определена специфика разных форм международной интеграции бирж: от фрормального сотрудничества до корпоративного слияния. Проанализирована специфика работы региональных биржевых объединений на примере MILA, SEE Link u Stock Connect. Определена ведущая роль информационно-коммуникационных провайдеров в построении современных глобальных биржевых сетей.

Ключевые слова: биржа, рынок капитала, сетевой эфффект, региональная интеграция, точка допуска.

\section{Fedir ZINCHENKO}

\section{The development of global exchange networks}

Introduction. For every exchange it is critical to maintain and spread its trading network. The desire to achieve so called liquidity effect is especially important in highly competitive environment in which modern trading platform are operating. The way exchanges expands their networks evolves and differs from country to country.

The purpose of the article is to analyze and define the characteristics of exchange networks establishment at the present stage of global capital market development, to specify different forms of integration among regulated markets, especially from developing countries.

(c) Федір Зінченко, 2018 
Results. The article investigates the influence of network or liquidity effects on the strategy of organized stock markets behavior. Two main directions of exchange networks development are revealed: through integration and by use of modern communication tools. Characteristics of different forms of exchanges international integration are defined: from formal cooperation to corporate merger. The specific functions of the most known regional organized stock markets integration are analyzed, by the example of MILA, SEE Link and Stock Connect. The leading role of information and communication providers in the construction of modern global stock exchanges networks has been identified.

Conclusions. Advantages that provide a network effect for organized stock markets leads to a different forms of stock exchanges cooperation - from formal agreements to full consolidation and mergers. At the same time, these processes are typical for exchanges from markets with different levels of development. With the rapid development of IT and algorithmic trading, the creation of stock exchange networks has significantly intensified globally. Striving to satisfy the demand of modern computerized traders, exchanges are in close cooperation with communication providers that own and operate world-wide optic-fiber networks.

Keywords: exchange, capital market, network effect, regional integration, point of presence.

JEL Classification: F30, G15, G23.

Постановка проблеми. Будь-яка біржа - це комунікаційна мережа. Відповідно до її внутрішніх правил, вона визначає, хто саме й які сигнали може по ній передавати, й як в кінцевому результаті ці сигнали перетворюються в біржові угоди.

У контексті мережевого характеру біржової діяльності можна виокремити два важливих аспекти. По-перше, переваги для кожного учасника торгівельної системи зростають у міру збільшення точок входу до цієї системи. По-друге, інвестор отримує додаткові блага від залучення до торгівельної системи нових учасників, оскільки зростає вірогідність укладання угоди на більш вигідних умовах. Процес зростання споживчої цінності мережі отримав назву мережевого ефекту.

Таким чином, для успішного функціонування торгівельному майданчику необхідно залучити критичну масу замовлень від інвесторів, запропонувавши останнім ефективний, прозорий і швидкий механізм укладання угод. 3 іншого боку, ліквідність можна покращувати збільшенням масштабів торгівельної мережі.
Аналіз останніх досліджень і публікацій. Одними із перших у контексті фондових торгівельних систем мережевий характер біржової діяльності дослідили Й. Домовіц та Б. Штайль [I. Domowitz, B. Steil], запровадивши поняття "ефекта ліквідності” [1]. І. Хасан та Х. Шмідель [I. Hasan, H. Schmiedel], проаналізувавши діяльність майже всіх основних європейських бірж, показали, що стратегія на розширення біржової мережі сприяє покращенню показників ліквідності, ринкового обороту, вартості укладання угод та витрат на утримання бірж [2].

Мета статті - проаналізувати та визначити особливості побудови біржових мереж на сучасному етапі розвитку світового ринку капіталу, розкрити зміст і специфіку інтеграційних об'єднань організованих ринків країн, що розвиваються.

Виклад основного матеріалу дослідження. Посилення мережевізації біржових платформ може відбуватись як на рівні одного майданчика, шляхом максимально- 
го розширення власної сітки, так й через інтеграцію мереж кількох бірж.

При цьому фінансова глобалізація та розвиток інформаційно-комунікаційних технологій позбавили процес біржової мережевізації географрічно-просторових меж. Як наслідок, інтеграція торгівельних платформ із кінця 1990-х рр. має виражено міжнародний характер. Кінцевою метою цього процесу є забезпечення глобальних інвесторів можливістю цілодобово торгувати акціями компаній із різних країн і регіонів.

Спектр інтеграції біржових мереж характеризується різноманітністю організаційно-правових форм (див. табл. 1). 3 одного краю цього спектра перебувають меморандуми про співпрацю як найслабша форма інтеграції, з іншого - консолідація у формі злиттів або поглинань як найвища форма інтеграції.

В цілому слабші форми об'єднання передбачають збереження ідентифрікації та незалежності бірж, що взаємодіють. На відміну від злиття, де один або кілька майданчиків припиняють існування як незалежні юридичні особи.

Слабкі форми інтеграції - це угоди щодо гармонізації правил лістингу, торгівлі та післяторгівельних процедур, а також розробка спільних регулятивних та опера- ційних стандартів діяльності [4]. Як правило, подібні угоди мають рамковий, рекомендаційних характер, а тому вкрай рідко закінчуються змістовним об'єднанням біржових мереж.

Технічне співробітництво дає змогу одним біржам отримувати у користування сучасні торгівельно-інформаційні системи (без втрати часу та матеріальних ресурсів на їх розробку), іншим - забезпечує додаткове джерело доходу. Перші, як правило, це майданчики із країн, що розвиваються, в більшості випадків із невеликими національними ринками цінних паперів. Другі представлені групою передових міжнародних або регіональних біржових операторів (Німецька біржа, NASDAQ OMX тощо).

Так, Німецька біржа розповсюджує ринкову інформацію, розраховує індекси та ліцензує їх для фондових бірж Ірландії, Мальти, Болгарії та Бомбею. Віденська фондова біржа співпрацює в галузі IT послуг із біржами Східної та Південної Європи (майданчики Будапешту, Любляни, Бухаресту, Сараєво, Загреба, Белграду), через використання спільної торгівельної системи, розробляє національні індекси, розповсюджує ринкову інформацію.

Стамбульська біржа в рамках власної спеціальної ініціативи “Євразійська мережа

Форми міжнародної інтеграції бірж*

Таблиця 1

\begin{tabular}{|c|c|c|}
\hline Назва & Зміст & $\begin{array}{c}\text { Організаційно-правова } \\
\text { форма }\end{array}$ \\
\hline $\begin{array}{l}\text { Формальне } \\
\text { співробітництво }\end{array}$ & $\begin{array}{l}\text { Крос-лістинг, крос-членство, уніфріковані правила } \\
\text { торгівлі }\end{array}$ & $\begin{array}{l}\text { Меморандуми } \\
\text { про взаємодію }\end{array}$ \\
\hline $\begin{array}{l}\text { Технічне } \\
\text { співробітництво }\end{array}$ & $\begin{array}{l}\text { Аутсорсинг систем розповсюдження ринкової } \\
\text { інформації, калькуляція індексів }\end{array}$ & $\begin{array}{l}\text { Контрактні } \\
\text { взаємовідносини }\end{array}$ \\
\hline $\begin{array}{l}\text { Торгівельне } \\
\text { співробітництво }\end{array}$ & $\begin{array}{l}\text { Спільна торгівельна система з єдиною книгою } \\
\text { замовлень із одночасним доступом брокерів } \\
\text { з різних бірж за уніфікованими правилами }\end{array}$ & Спільні підприємства \\
\hline Злиття та поглинання & $\begin{array}{l}\text { Консолідація фрінансових, управлінських, } \\
\text { торгівельних, маркетингових функцій }\end{array}$ & Холдингові компанії \\
\hline
\end{tabular}

* Складено на основі [3]. 
розповсюдження інформації" надає відповідні послуги біржам Сараєво, Чорногорії, Македонії та Карачі.

Одним із лідерів експорту різноманітних IT-рішень в біржовій галузі $є$ Корейська біржа. Головними споживачами її розробок $€$ майданчики Південно-Східної та Центральної Азії. Окрім продажу технологічних систем, KRX спеціалізуються на "експорті досвіду” роботи біржових ринків. Так, Корейська біржа виступила головним радником у створенні майданчиків у Лаосі та Камбоджі - країнах, де організовані ринки цінних паперів до цього взагалі були відсутні. В обох випадках нові біржі, які розпочали діяльність у 2011 та 2012 рр., було створено у формі спільних підприємств між корейською компанією та відповідними національними регуляторами. При цьому частка KRX у фондовій біржі Лаосу склала 49\%, Камбоджі - 45\% [5].

Деякі дослідники вважають, що в такий спосіб корейський біржовий оператор прагне популяризувати власні технологічні стандарти, намагаючись зробити їх міжнародними, що спростить у майбутньому залучення нових клієнтів [5].

Технічне співробітництво може бути частиною більш загальних угод про стратегічне партнерство. Так, в рамках подібної угоди, починаючи з 2009 р., біржа Осло використовує торгівельну систему розробки групи Лондонської фондової біржі. Окрім цього, майданчики співпрацюють у питаннях нагляду за ринком і розподілом інформації 3 метою виконання регулятивних функцій.

Торгівельне співробітництво полягає в організації між різними фондовими майданчиками спільної мережі для торгівлі цінними папери. Подібний зв'язок між біржами дає змогу інвестору з певного національного ринку торгувати не лише місцевими фінансовими інструментами, а й іноземними. В спільній мережі всі замовлення щодо пев- ного цінного паперу, незалежно від резидентності торгівця, переадресовуються до біржового списку відповідного майданчику.

В основі спільних біржових мереж лежить поняття, яке отримало в науковій літературі назву “неявних злиттів" (від англ. Implicit Mergers). Подібне об’єднання - це домовленість між біржами, коли всі цінні папери, що пройшли лістинг на одному майданчику, автоматично вважаються такими й для інших, разом із цим всі торговці, що оперують на одній біржі, вважаються членами та/або отримують віддалений доступ до інших [6].

На практиці найвдалішим прикладом подібного “неявного злиття" був альянс NOREX, який був першим об'єднанням подібного типу. Альянс розпочав свою діяльність у 1999 р. із угоди між фондовими біржами Стокгольму та Копенгагену. До 2004 p. NOREX поєднав всі біржі Північної Європи та Балтії. В рамках об'єднання 8 майданчиків користувалися спільною торгівельною системою SAXESS, використовували гармонізовані правила торгівлі та допуску на ринок.

Використання інтегрованої платформи дало змогу біржам - учасницям альянсу значно покращити показники ліквідності власних ринків. Так, до 2005 р. обсяги торгівлі біржі Копенгагену зросли на 217\%, Ісландської біржі - на 470\%, бірж Осло та Таллінна - на 220\% та 190\%, відповідно [7].

NOREX альянс припинив існування, еволюціонувавши в вищу форму інтеграції - біржовий холдинг OMX, в який не увійшов лише головний торгівельний майданчик Норвегії, що уклав зазначену вище стратегічну угоду із групою Лондонської фондової біржі.

Сьогодні торгівельне співробітництво розглядається як один із найлегших способів інтеграції національних організованих ринків капіталу, оскільки базується на технологічних принципах та не зачіпає склад- 
ні політичні аспекти. Саме тому цей спосіб співробітництва розповсюджений серед країн, що розвиваються, в межах одного регіону та використовується останніми в ході інтеграції власних невеликих за обсягами ринків цінних паперів з метою підвищення їх привабливості для інвесторів.

Регіональна інтеграція ринків капіталу може мати позитивний вплив на діяльність усіх його стейкхолдерів із країн-учасниць. До них можна віднести наступні:

1) утворюється більш великий та ефективний ринок, що покращує передумови залучення капіталу на первинному ринку та поглиблює вторинний ринок, збільшуючи його активність та ліквідність;

2) зростає зацікавленість регіоном як єдиним, а не фрагментованим ринком збоку іноземних портфельних інвесторів;

3) поряд із традиційними цінними паперами ринку капіталу з'являється можливість для пропозиції іноземним інвесторам регіональних похідних фінансових інструментів, наприклад ф'ючерсів, опціонів, що базуються на різноманітних місцевих індексах;

4) забезпечується краща основа для можливої приватизації великих компаній, в тому числі за участі місцевих інституційних інвесторів;

5) місцеві приватні корпорації потенційно отримують більші пули інвестиційного ресурсу, а також можливість розширити впізнаваність власного бренду на регіональному рівні, таким чином розширивши власний ринок;

6) покращуються стандарти брокерської та дилерської діяльності за рахунок економії на масштабі через використання уніфікованих торгівельних систем на різних ринках. Окрім цього, брокери змушені будуть покращувати рівень якості своїх послуг через зростання конкуренції із торговцями інших країн-учасниць об'єднання. Ті, які виявляться більш конкурентоспроможними, зможуть генерувати більші прибутки у майбутньому;

7) покращується якість корпоративного управління до рівня міжнародних стандартів через збільшення іноземних портфрельних інвестицій;

8) місцеві великі корпорації можуть проходити лістинг на регіональному майданчику, таким чином збільшуючи його капіталізацію до рівня розвинутих ринків, що може інтенсифікувати увагу міжнародних інвесторів до регіону;

9) значні витрати на підтримку та удосконалення спільної технологічної платформи можуть бути розподілені між біржами-учасницями.

Переваги регіонального об'єднання фондових ринків обумовили появу подібних процесів у всіх частинах світу (див. табл. 2); найбільш відомими з них є: в Латинський Америці - MILA; в Європі - SEE Link; в Азії - ASEAN Trading Link; в Африціоб'єднання в рамках Економічного співтовариства країн Західної Африки.

Першим та найбільш успішним із цих проектів був - Інтегрований Латиноамериканський ринок, або MILA (від ісп. - Mercado Integrado Latinoamericano). Проект було ініційовано фрондовими біржами та депозитаріями Чилі, Перу та Колумбії у 2009 р. Перші операції із акціями розпочалися у травні 2011 р. Пізніше в рамках ширшого інтеграційного процесу - створення Тихоокеанського альянсу - до MILA приєднався холдинг Мексиканської біржі.

Станом на 2017 р. в рамках проекту вдалося досягти наступного:

1. Лістинг цінних паперів на одній біржі означає автоматичний допуск до торгів на інших трьох майданчиках.

2. Дозволено випуск та транскордонний обіг будь-яких фрінансових інструмен- 
Порівняльна характеристика біржових регіональних об'єднань

\begin{tabular}{|c|c|c|c|c|}
\hline & MILA & $\begin{array}{c}\text { ASEAN Trading } \\
\text { Link }\end{array}$ & SEE Link & $\begin{array}{l}\text { Stock } \\
\text { Connect }\end{array}$ \\
\hline Біржі ініціатори & $\begin{array}{c}\text { Чилійська, Перуан- } \\
\text { ська та Колумбійська }\end{array}$ & \begin{tabular}{|c|} 
Сінгапурська та \\
Малайзійська
\end{tabular} & $\begin{array}{c}\text { Македонська, Болгар- } \\
\text { ська та Загребська }\end{array}$ & $\begin{array}{l}\text { Гонконгська, } \\
\text { Шанхайська }\end{array}$ \\
\hline $\begin{array}{l}\text { Біржі, що } \\
\text { приєдналися }\end{array}$ & Мексиканська & Таїландська & $\begin{array}{c}\text { біржі Белграду, Любляни, } \\
\text { Сараєво та Баня-Луки }\end{array}$ & $\begin{array}{c}\text { Шеньчжен- } \\
\text { ська }\end{array}$ \\
\hline Рік початку роботи & 2011 & 2012 & 2016 & $2014 / 2016$ \\
\hline Рік закінчення роботи & - & 2017 & - & - \\
\hline $\begin{array}{l}\text { Інструменти, } \\
\text { що обертаються }\end{array}$ & $\begin{array}{c}\text { Пайові, боргові ЦП, } \\
\text { деривативи }\end{array}$ & Пайові ЦП & $\begin{array}{c}\text { Пайові та державні бор- } \\
\text { гові ЦП }\end{array}$ & Пайові ЦП \\
\hline $\begin{array}{l}\text { Післяторгівельна } \\
\text { інтеграція }\end{array}$ & - & - & - & + \\
\hline
\end{tabular}

* Складено за даними Інтернет-сайтів відповідних об'єднань.

тів після згоди одного із відповідних національних регуляторів (окрім облігацій для Мексики, оскільки вони обертаються на позабіржовому ринку).

3. Доступ брокерів до майданчиків учасників відбувається через місцевих уповноважених торговців.

4. Використовується один торгівельний інтерфейс для Чилі, Колумбії та Перу.

5. Закінчується робота над стандартизованими вимогами для проспектів емісії.

6. У співробітництві зі світовим провідним індекс-агентством S\&P Dow Jones Indeces створено фондові індекси S\&P MILA Pacific Alliance Select та S\&P MILA Andean 40, що відслідковують рух 60 та 40 найбільших компаній регіону, відповідно [8].

Проект SEE Link було започатковано як спільне підприємство із штаб-квартирою у Скоп'є, засновниками якого виступили на рівноправній основі фондові біржі Македонії, Болгарії та Загребу. Фінансову підтримку в розмірі 540 тис. євро було надано ЄБРР. Пізніше до проекту приєдналися біржі Белграду, Любляни, Сараєво та Баня-Луки.

В основі SEE Link $€$ спеціальне програмне забезпечення, що дає змогу трейдерам оперувати на будь-якій із бірж учас- ниць, не будучи ії̈ членом та/або не маючи прямого доступу до торгів. Торгівля відбувається опосередковано через іноземного брокера-кореспондента [9].

Брокер-ініціатор направляє замовлення через систему SEE Link на брокера-виконавця в іншій країні. Останній переправляє замовлення на виконання на відповідну біржу, на якій він авторизований. Після того, як угода буде укладена, брокер-виконавець пересилає брокеру-ініціатору звіт про виконання. При цьому біржа-учасник мережі постійно надсилає через систему брокерамініціаторам ринкову інфоомацію щодо поточних котирувань, новини компаній та інші повідомлення. Такий принцип роботи SEE Link нагадує систему переадресації замовлень між різними національними ринками.

Незважаючи на потенційні переваги та відносну простоту реалізації на практиці, регіональні біржові мережі поки що не виправдовують очікуваних оптимістичних результатів. Так, обсяг угод в рамках MILA станом на 2016 р. був менший одного відсотка сумарної вартості внутрішніх транзакцій окремих майданчиків. При цьому найбільша кількість угод відбувалась із цінними паперами чилій- 
ських компаній-емітентів, а ініціаторами їх були перуанські інвестори [10].

Більше того, позитивний ефект міжнародної диверсифікації інвестиційного портфелю, який став можливим завдяки спрощенню виходу інвесторів на сусідні ринки, обернувся протилежним результатом. Так, К. Мелладо та Д. Ескобарі [C. Mellado, D. Escobari], використовуючи модель динамічних умовних кореляцій, виявили, що створення MILA призвело до значного зростання кореляції між доходністю національних фондових ринків країн-учасниць. Це, в свою чергу, вказує на зменшення позитивного ефректу диверсифрікації портфелю, що буде складатися із акцій компаній країнучасниць MILA [11].

Проект біржової мережі в рамках ACEАН взагалі було припинено, оскільки не було достатнього попиту з боку брокерів, які ще до запровадження ініціативи витратили ресурси на побудову власних зв'язків із ринками іноземних країн-учасниць.

Головний недолік регіональних біржових об'єднань полягає в тому, що вони базуються на міжброкерських відносинах. Інвестор, якщо хоче провести угоду із акціями іноземної біржі, надсилає їі місцевому брокеру, а той - брокеру-кореспонденту із країни емісії цінного паперу. Як наслідок, збільшуються витрати на проведення операції та зменшується ефективність всієї системи. На всіх розвинутих ринках це нівелюється розповсюдженою практикою прямого віддаленого доступу, яка передбачає взаємне визнання членів бірж із різних країн.

Також розглянуті регіональні інтеграційні рішення передбачають, що всі обов'язки щодо клірингу та розрахунків за укладеними угодами покладені на брокерів бірж, де цінні папери пройшли лістинг. Це значно збільшує ризики невиконання зобов'язань, порівняно із сучасними системами, де використовують центральні контрагенти.
Окрім цього, успішний розвиток регіонального біржового співробітництва залежить від гармонізації великої кількості різноманітних регулятивних норм, серед яких можна виокремити наступні:

- системи оподаткування операцій із фрінансовими інструментами;

- наявність валютного контролю та обмежень;

- політика щодо закордонних інвестицій як інституційних, так й індивідуальних інвесторів;

- практика корпоративного управління.

Прикладом вдалої реалізації міжбіржового торгівельного співробітництва $€$ угода Гонконгської фондової біржі із майданчиками континентального Китаю в Шанхаї та Шеньчжені [12]. На відміну від розглянутих вище проектів, успіх зазначеної кооперації обумовлений серед іншого такими факторами:

1. Вихід торговців на торгівельну платформу із іншої юрисдикції без посередництва іноземного брокера.

2. Наявність угоди між кліринговими інститутами обох сторін (Chinaclear та Hong Kong Securities Clearing Company Limited), що зменшує трансакційні ризики.

3. Величезний попит із боку іноземних інвесторів, які через Гонконгську біржу отримали єдиний спосіб інвестувати в акції китайських компаній типу А (номіновані в юанях та обертаються виключно на майданчиках Шеньчженя та Шанхаю).

4. Попит з боку інвесторів материкового Китаю, обумовлений можливістю диверсифрікації та арбітражу із акціями типу $\mathrm{H}$ (китайських компаній, що пройшли лістинг на гонконгській біржі).

Як наслідок, за три роки від початку діяльності у 2014 р. загальний торгівельний обсяг угод в рамках системи Stock Connect між майданчиками Гонконгу та Шанхаю, "в північному" та "південному напрямках", на початок 2018 р. перевищив 
1 трлн дол. США. Окрім цього, в рамках спільної торгівельної системи із Шеньчженською біржею за рік від початку її роботи, було укладено угод на загальну вартість 214 млрд дол. США. При цьому майже 67\% від цієї суми припало на операції на "континентальному" майданчику [13].

На відміну від майданчиків із граничних ринків та ринків, що фооруються, інтеграційні процеси серед бірж розвинутих країн відбуваються у формі злиттів та поглинань. На макроекономічному рівні цим процесам сприяють відсутність обмежень на рух капіталу та накопичений юридично-організаційний досвід реалізації угод щодо об'єднання компаній. На рівні бізнесу консолідація пояснюється бажанням досягти синергічного ефректу від розподілу фріксованих витрат і диференціації джерел доходу. Це, в свою чергу, дає можливість власникам бірж отримувати більші прибутки.

Згідно 3 дослідженнями І. Хacaна, Н. Шмидля та Л. Сонга [І. Hasan, H. Schmiedel, L. Song] інтеграційні процеси $є$ позитивними для власників-акціонерів біржових операторів. Проаналізувавши за період з 2000 по 2008 рр. 110 угод щодо різноманітної кооперації за участю 14 бірж світу, вчені виявили позитивний зв'язок між зростанням вартості акцій майданчиків та інтеграційними процесами, в яких вони беруть участь. При цьому ринкова вартість зростає більше за умови участі біржі в процесах злиття та поглинання, а ніж при слабших формах інтеграції [14].

Розвиток інформаційних технологій та лібералізація руху капіталу дали змогу кожній окремій біржі збільшувати власний пул ліквідності без участі в інтеграційних процесах з іншими майданчиками. Використовуючи сучасні телекомунікаційні засоби, біржі здатні розширювати географію своїх торгівельних мереж й в такий спосіб залучати більше учасників то торгів.
Структура сучасної світової фрінансової архітектури обумовлює намагання більшості провідних торгівельних платформ охопити власними мережами якомога більшу кількість міжнародних фрінансових центрів, оскільки останні - це місце концентрації sell- та buy-side компаній. 3 цією метою біржі організовують так звані "точки допуску" або "присутності" (від англ. "Point of Presence" (POP), "Point of Access") у датацентрах, що розташовані у відомих фрінансових хабах. РОР - це окрема одиниця комунікаційного устаткування, яке поєднано напряму через канали зв'язку із головним сервером біржі. У такий спосіб інвестиційні компанії, що перебувають у фрінансовому центрі, отримують швидкий доступ до ядра торгівельної системи.

Географрія присутності кожної окремої біржі варіюється залежно від масштабів її діяльності. Так, швейцарська фрондова біржа SIX Swiss має лише одну точку допуску - у сусідньому Франкфурті. Головний австралійський майданчик ASX через свою мережу ASX Net Global забезпечує зв'язок власного дата-центру із фрінансовими центрами Сінгапуру, Гонконгу, Чикаго та Лондона.

Холдинг Німецької біржі має у своєму складі окремий підрозділ, що відповідальний за забезпечення глобального безперебійного допуску до власної торгівельної системи Т7 (Xetra). При цьому мережа дає змогу отримувати ринкову інформацію та надсилати замовлення не лише на платформи, що знаходяться безпосередньо в управлінні Німецької біржі (Франкфруртська фондова біржа, Xetra, Eurex), а й до майданчиків інших країн - Ірландської, Болгарської, Віденської, Мальтійської, Сінгапурської, біржі Кайманових островів та інших

Однак найбільш розгалуженою мережею оперує холдинг Intercontinental Exchange. Підрозділ холдингу ICE Data Services забезпечує різноманітні варіанти 
доступу учасників ринку не лише на багаточисельні власні майданчики, а й на 150 торгівельних платфрорм різних груп активів, що розташовані у всіх частинах світу.

Високий рівень технологізації та роботизації операцій із фрінансовими інструментами висуває особливі вимоги до біржових мереж, як ліній зв'язку, що поєднують торгівельний сервер із трейдерами. Значна частка торгів із фінансовими інструментами, зокрема акціями, на розвинутих ринках відбувається через використання алгоритмічної, зокрема високочастотної торгівлі. Для компаній, що використовують подібні інвестиційні стратегії, на перший план виходить пропускна здатність, надійність, швидкість передачі інформації та час відгуку або затримки (анг. - Latency) каналів зв'язку між торгівельним майданчиком та інвестором. Саме використання оптимальної мережі із найменшим часом затримки від подачі ринкової заявки та відгуком з торгівельного серверу дає торговцям конкурентні переваги та можливість отримувати прибутки.

Сьогодні найдосконалішим фрізичним середовищем для передачі великих потоків інформації (в тому числі фрінансово-ринкової) на значні відстані $€$ "оптичне волокно" [15]. Саме волоконно-оптичні лінії зв'язку користуються особливим попитом серед постачальників та споживачів комунікаційних послуг у всьому світі. Серед переваг такого типу вирізняють: довговічність, економність, малий об'єм та вагу, електробезпеку, високу пропускну здатність та швидкість передачі даних без використання ретрансляторів тощо.

У 2010 р. вперше було введено в експлуатацію наземний оптичний кабель з метою використання виключно для електронної торгівлі фінансовими інструментами. Компанія Spread Networks поєднала Чикаго, де розміщений сервер Чиказької товарної біржі, із Нью-Джерсі, місцем розташуван- ня дата-центру Nasdaq. Лінія дала змогу зменшити час затримки із 17 до 13 мілісекунд. Першим підводним кабелем, введеним в експлуатацію у 2015 р. виключно для учасників фрінансового ринку, став Hibernia Express. Лінія з'єднала провідні світові фрінансові центри - Лондон та Нью-Йорк [16].

Вказані наземні та підводні мережі перебувають у власності корпорацій, які спеціалізуються на наданні інформаційно-комунікаційних послуг, в тому числі розроблених спеціально під потреби фрінансового сектоpy. Найвідомішими з них сьогодні $є$ Colt, Transaction Network Services, CenturyLink, SIA Group, Options, IPC Systems та інші. Taким чином вказані корпорації стають важливими учасниками інфраструктури ринку капіталів.

Висновки. Переваги, що забезпечує мережевий ефект для організованих фондових ринків, обумовлюють різноманітні форми кооперації біржових майданчиків: від формального співробітництва до повної консолідації та злиття юридичних осіб. Ці процеси $є$ характерними для бірж із ринків різного рівня сформованості. Зі стрімким розвитком IT та алгоритмічної торгівлі побудова біржових мереж відчутно інтенсифрікувалась у глобальному масштабі. Намагаючись задовольнити попит сучасних комп'ютеризованих трейдерів, біржі вступають у близьке співробітництво із комунікаційними провайдерами, що володіють та оперують всесвітніми оптико-волоконними мережами.

\section{Список використаних джерел}

1. Domowitz I. Automation, trading costs and the structure of the securities trading industry / I. Domowitz, B. Steil // Brookings-Wharton Papers on Financial Services. - 1999.

2. Hasan I. Do networks in the stock exchange industry pay off? European evidence / I. Hasan, H. Schmiedel// Bank of Finland Discussion Paper. 2003. 
3. Лауфрер М.А. Глобализация финансовых рынков на рубеже тысячелетий / М.А. Лайфрер // Финансы и кредит. - 2000. - № 6 (66). - C. 38.

4. Carretta A. Integration of European securities markets and links among stock exchanges: a cross-listing, cross-membership and cross-trading analysis [Electronic resource] / A. Carretta, G. Nicolini. - Access mode : http://www.consumer-finance. org/Nicolini/Publications.htm.

5. Hiromi H. Korea exchange's global strategy: opportunities and challenges [Electronic resource] / H. Hiromi // Nomura Journal of Capital Markets. 2013. - Vol. 4, No 4.- Access mode : http:// www.nicmr.com/nicmr/english/report/repo/2013/ 2013spr05.pdf.

6. Di Noia, C. The stock-exchange industry: network effects, implicit mergers and corporate governance / C. Di Noia // MARZO Working Paper. 1999. - № 33. [Electronic resource]. - Access mode : SSRN: http://dx.doi.org/10.2139/ssrn.200991.

7. Mohd Sani I. Enhancing cooperation \& regional integration of ASEAN equity market [Electronic resource] / I. Mohd Sani // OECD-ADBI 12th Roundtable on Capital Market Reform in Asia, Tokyo. - 7 February 2012. - Access mode : http:// www.oecd.org/finance/financial-markets/49700649. pdf - C. 12.

8. S\&P MILA Andean 40 [Electronic resource] / S\&P Dow Jones Indeces. - Access mode : https:// us.spindices.com/indices/equity/sp-mila-andean40-index

9. Dimitrov I. SEE Link connecting markets [Electronic resource] / I. Dimitrov / SEE Link, BSE - Sofia Belgrade, March 15, 2016. - Access mode : http://www.see-link.net/publications/36.

10. Perry G. Financial integration in the Pacific Alliance [Electronic resource]/G. Perry, D. Auvert // Inter-American Development Bank. - 2017. - Access mode : http://dx.doi.org/10.18235/0000395.

11. Mellado $C$. Virtual integration of financial markets: a dynamic correlation analysis of the creation of the Latin American integrated market / C. Mellado, D.Escobari// MPRA Paper. - 2014. -
Access mode : https://mpra.ub.uni-muenchen.de/ id/eprint/60958.

12. What is stock connect [Electronic resource] / Hong Kong Exchanges and Clearing Limited. Access mode : https://www.hkex.com.hk/MutualMarket/Stock-Connect?sc_lang=en.

13. Власні розрахунки на підставі HKEX Fact Book [Electronic resource] / Hong Kong Exchanges and Clearing Limited - 2018. - Access mode : https://www.hkex.com.hk/Market-Data/ Statistics/Consolidated-Reports/HKEX-FactBook?sc_lang=en

14. Hasan I. Growth strategies and value creation what works best for stock exchanges? [Electronic resource] / I. Hasan, H. Schmiedel, L. Song // Bank of Finland Research Discussion Paper. 2010. - №2/2010. - Access mode : http://ssrn.com/ abstract_id=1559888.

15. Осадчук В.С. Волоконно-оптичні системи передачі : навч. посіб. / В.С. Осадчук, О.В. Осадчук - Вінниця : ВНТУ, 2005.

16. Eichengreen B. Cables, Sharks and Servers: technology and the geography of the foreign exchange market [Electronic resource] / B. Eichengreen, R. Lafarguette, A. Mehl // European Central Bank Working Paper Series. - 2016. - № 1889. Access mode : https://www.ecb.europa.eu/pub/research/working-papers/html/papers-2016.en.html

\section{References}

1. Domowitz, I. \& Steil, B. (1999). Automation, trading costs and the structure of the securities trading industry. Brookings-Wharton Papers on Financial Services.

2. Hasan, I. \& Schmiedel, H. (2003). Do networks in the stock exchange industry pay off? European evidence. Bank of Finland Discussion Paper.

3. Laufer, M.A. (2000). Globalizatsyia finansovyh rynkov na rubezhe tysiacheletii [Globalization of financial markets at the millennia turn]. Finansy $i$ kredit Finance and Credit, 6 (66), 38 [in Russian].

4. Carretta, A. \& Nicolini, G. (2006). Integration of European securities markets and links among stock exchanges: a cross-listing, cross-membership 


\section{ФIHAНСОВI РИНКИ}

and cross-trading analysis. Available at: http://www. consumer-finance.org/Nicolini/Publications.htm.

5. Hiromi, H. (2013). Korea exchange's global strategy: opportunities and challenges. Nomura Journal of Capital Markets, 4. (Vol. 4). Available at: http://www.nicmr.com/nicmr/english/ report/repo/2013/2013spr05.pdf

6. Di Noia, C. (1999). The stock-exchange industry: network effects, implicit mergers, and corporate governance. MARZO Working Paper, 33. Available at: http://dx.doi.org/10.2139/ssrn.200991.

7. Mohd Sani, I. (2012). Enhancing cooperation \& regional integration of ASEAN equity market. OECD-ADBI 12th Roundtable on Capital Market Reform in Asia. Tokyo: OECD. Available at: $\quad$ http://www.oecd.org/finance/financial-markets/49700649.pdf.

8. S\&P MILA Andean 40. S\&P Dow Jones Indeces. Available at: https://us.spindices.com/indices/equity/sp-mila-andean-40-index.

9. Dimitrov, I. (2016). SEE Link connecting markets. SEE Link, BSE. Sofia Belgrade. Available at: http://www.see-link.net/publications/36

10. Perry, G. \& Auvert, D. (2017). Financial integration in the Pacific Alliance. Washington. InterAmerican Development Bank. Available at: http:// dx.doi.org/10.18235/0000395.

11. Mellado, C. \& Escobari, D. (2014). virtual integration of financial markets: a dynamic corre- lation analysis of the creation of the Latin American integrated market. MPRA Paper. Available at: https://mpra.ub.uni-muenchen.de/id/eprint/60958.

12. What is stock connect. (2018). Hong Kong Exchanges and Clearing Limited. Available at: https://www.hkex.com.hk/Mutual-Market/StockConnect?sc_lang=en.

13. Vlasni rozrahunky na pidstavi HKEX Fact Book [Author's calculation based on HKEX Fact Book]. (2018). Hong Kong Exchanges and Clearing Limited. Available at: https://www.hkex.com. hk/Market-Data/Statistics/Consolidated-Reports/ HKEX-Fact-Book?sc_lang=en.

14. Hasan, I., Schmiedel, H., Song, L. (2010). Growth strategies and value creation what works best for stock exchanges? Bank of Finland Research Discussion Paper, 2/2010. Available at: http://ssrn.com/abstract_id=1559888.

15. Osadchuk, V.S. \& Osadchuk, O.V. (2005). Volokonno-optychni systemy peredachi [Fiber optic transmission systems]. Vinnytsia: VNTU [in Ukrainian].

16. Eichengreen, B., Lafarguette, R., Mehl, A. (2016). Cables, Sharks and Servers: technology and the geography of the foreign exchange market. European Central Bank Working Paper Series, 1889. Available at: https://www.ecb.europa.eu/pub/ research/working-papers/html/papers-2016.en.html

Стаття надійшла до редакції 11.09.2018. 